\title{
Oral Health and Nicotine Replacement Therapy Product
}

\author{
Jane Manakil, Andrew Miliankos, Megan Gray, Anut Itthagarun, Roy George \\ School of Dentistry and Oral Health, Griffith University, Gold Coast, Australia
}

\section{Abstract}

Nicotine replacement therapy (NRT) products are used extensively for assisting users in achieving cessation goals through the substitution of pure nicotine with tobacco-less products. Awareness of the adverse oral effects of nicotine replacement products is important for health practitioners. This review highlights the potential effects of NRT products on the oral tissues and management of these adverse effects. Cochrane, PubMed, and MEDLINE electronic databases were utilized in search of the relevant literature related to NRT. The review highlights various adverse effects on oral health status from NRT products, with the underlying mechanisms for these effects remaining inconclusive. There is a need for more education of health professionals in oral health promotion and maintenance in these cases. NRT products have many potential adverse effects on oral health, and it is the responsibility of dental professionals to consider these in the management of patients to optimize a beneficial clinical outcome.

Keywords: Mouth neoplasms, nicotine replacement products, oral health, periodontal diseases, smoking, tobacco

\section{INTRODUCTION}

Tobacco-related addiction has huge financial implications, not only for the users but also for the public. ${ }^{[1,2]}$ While rates of smoking are declining in $2015,11.5 \%$ of global deaths were attributable to smoking worldwide. ${ }^{[3]}$

A key objective of the Government and all health professionals is to eliminate or to reduce the impact of tobacco usage on the wider population. Current knowledge about tobacco use and its effects has led to the understanding that there is no safe way to use tobacco and that total cessation is imperative to avoid any number of debilitating and eventually fatal conditions. ${ }^{[4]}$

Various methods of achieving cessation have been proposed, including behavioral counseling and pharmacotherapy. The paradigm for cessation has changed over the years with a shift toward viewing addiction as a disease and the contemporary approach toward the management of tobacco addiction centers around a combination of education, counseling, and pharmacotherapy. ${ }^{[5]}$

A method of assisting users in achieving cessation goals has been through the substitution of pure nicotine with tobacco-less products. ${ }^{[6]}$ Nicotine replacement products (NRPs) are the collective name for a range of over-the-counter medications containing pure nicotine, designed to aid users of tobacco

\begin{tabular}{|l|l|}
\hline \multicolumn{3}{c|}{ Access this article online } \\
\hline Quick Response Code: & Website: \\
& www.ejgd.org \\
\hline
\end{tabular}

products in reducing their intake of such products, or to achieve a total cessation of use. ${ }^{[1,7,8]}$ This pathway reduces the withdrawal symptoms associated with a reduction of intake or total cessation. ${ }^{[1,7,8]}$ The use of nicotine substitution through one or more NRPs to aid cessation of tobacco use is termed as nicotine replacement therapy (NRT), and in the contemporary setting is considered as first-line therapy for smoking cessation.

NRT products are available in many different forms for consumers, including chewing gums, ${ }^{[9]}$ lozenges or mints, ${ }^{[10]}$ inhalers, ${ }^{[11]}$ patches ${ }^{[12]}$ and vaporizers (also called E-cigarettes or Electronic cigarettes). ${ }^{[13]}$ Nicotine drinks, straws, and lollipops are other developed and marketed products. ${ }^{[14]}$ These products are available in varying strengths of nicotine based on the tobacco user's habitual intake or "stage of quitting." Except for nicotine patches (where nicotine is absorbed transdermally) and nasal sprays (where nicotine is absorbed through nasal mucosa), all other forms of NRP deliver nicotine

Address for correspondence: Prof. Roy George, Discipline Lead Endodontics, School of Dentistry and Oral Health, Griffith University, Gold Coast, Australia. E-mail: drroygeorge@gmail.com

This is an open access journal, and articles are distributed under the terms of the Creative Commons Attribution-NonCommercial-ShareAlike 4.0 License, which allows others to remix, tweak, and build upon the work non-commercially, as long as appropriate credit is given and the new creations are licensed under the identical terms.

For reprints contact: reprints@medknow.com

How to cite this article: Manakil J, Miliankos A, Gray M, Itthagarun A, George R. Oral health and nicotine replacement therapy product. Eur J Gen Dent 2020;9:1-6.

Received: $15^{\text {th }}$ July, 2019 Revision: $31^{\text {st }}$ October, 2019

Accepted: $17^{\text {th }}$ November, 2019 Publication: $02^{\text {nd }}$ January, 2020 
by transmucosal absorption across the lining of the mouth. Oral delivery systems pose potential implications for the soft- and hard-tissue structures of the oral cavity, and the popularity of oral delivery methods highlights the need for integration of knowledge of potential adverse effects and how these may modify treatment outcomes or risk profiles in an oral and dental context.

NRT products are reported to be an effective adjunct to professional counseling, and other pharmacological aids in achieving sustained abstinence from tobacco $0^{[1,5,7,8,12,15,16]}$ with some studies reporting success rates as high as 33\% compared to $5 \%$ with patients quitting on their own. ${ }^{[1]}$ One meta-analysis found a $50 \%-70 \%$ higher chance of quitting when using NRT. ${ }^{[17]}$ Interestingly, NRT has shown to be effective in achieving sustained abstinence, even in smokers who have no intention of quitting. ${ }^{[8]}$

Combination therapy is a term referring to the use of multiple, different forms of NRT product simultaneously, for example, a nicotine patch used in conjunction with a nicotine spray. ${ }^{[14,18]}$ It has been shown to be more effective for cessation than the use of anyone product on its own, independent of the provision of any professional counseling. ${ }^{[5,7,8,15,16]}$ Combination therapy is often used when initial attempts at cessation with monotherapy (the use of one form of NRT product) has failed to show positive benefit. ${ }^{[12]}$

\section{The Effects of Nicotine on the Body}

Nicotine is the most pharmacologically active component of tobacco and has a wide range of effects on the body, affecting blood flow, the immune response, and the body's healing mechanisms. ${ }^{[19-23]}$ Nicotine has been noted to inhibit revascularization, ${ }^{[24]}$ has a direct effect on the function and action of immune cells, ${ }^{[25-29]}$ impedes tissue-repair mechanisms ${ }^{[24,30-37]}$ in the body, and affects almost every organ in the body, including the brain and the heart. ${ }^{[23,38,39]}$ Some of the more specific pharmacokinetics of nicotine are outlined below.

\section{Neurological and cardiovascular effects of nicotine}

Nicotine has a very targeted and direct active effect on the nervous systems; nicotinic cholinergic receptors are found in the brain, autonomic ganglia, and the neuromuscular junction. ${ }^{[23]}$ Intake of nicotine into the body enhances the release of various neurotransmitters, including adrenaline, noradrenaline, dopamine, acetylcholine, serotonin, vasopressin, glutamate, nitric oxide, calcitonin growth-related peptide and beta-endorphin ${ }^{[19,23]}$ producing a myriad of systemic effects.

The main cardiovascular effect of nicotine is sympathetic neural stimulation. ${ }^{[20]}$ Nicotine exposure can increase the heart rate by up to $10-15$ beats/min and increase blood pressure by up to $5-10 \mathrm{mmHg} .{ }^{[20]}$ Nicotine's inhibitory effects on angiogenesis and blood flow locally and systemically $^{[40,41]}$ have ramifications not only in a broader general health context but also its vasoconstrictive properties lend itself toward the impairment of salivary flow in the oral environment and has such as implications on a patient's caries-risk profile. Furthermore, opportunistic oral bacterial infections such as Candidiasis has been reported as a result of low salivary flow. ${ }^{[42-45]}$

Immunological effects and effect on the healing response Nicotine has profound immunological effects, influencing all aspects of the immune system, including alterations in humoral and cellular immunity. ${ }^{[29]}$ It has been shown to have a range of immunosuppressive actions, ${ }^{[27,29,46-48]}$ including inhibition of pro-inflammatory cytokines in macrophages, inhibition of adhesion molecules, and inhibiting proliferation of lymphocytes in the human mixed lymphocyte reaction. ${ }^{[48]}$ Nicotine has been observed to directly impair interleukin-1 $\beta$ and superoxide and hydrogen peroxide formation by monocytes as well as the formation of oxygen radical species by neutrophils, effectively inhibiting the defensive functions of these immune cells. ${ }^{[49,50]}$

Nicotine exposure has also been shown to inhibit a range of normal neutrophil functions such as phagocytosis, integrin expression, and protease inhibitor production, ${ }^{[1]}$ leading to inhibition of the effectiveness of these immune cells on the body.

It has been documented that nicotine inhibits the actions of B-cells and T-cells ${ }^{[28,46]}$ and impairs antigen receptor function and ectonucleotidase activity in lymphocytes, ${ }^{[25,26,52]}$ weakening the capacity for these immune cells to respond normally.

Nicotine has been shown to impair cutaneous wound healing, ${ }^{[30,31]}$ normal bone healing responses, ${ }^{[32,33]}$ revascularization of both hard and soft tissues, ${ }^{[24,31,32]}$ as well as healing of the bone following graft and augmentation, ${ }^{[24,34]}$ which may be related to the inhibition of various cytokines involved in revascularization and osteoblast differentiation, ${ }^{[53]}$ and therefore affecting the healing of both hard and soft tissues of the body. Similarly, nicotine affects fibroblast attachment, ${ }^{[35-37]}$ integrin expression ${ }^{[54]}$ and inhibits collagen production while enhancing collagenase production, ${ }^{[55]}$ leading to impairment of the normal healing response. In a recent publication, it was observed that when nicotine gum was placed directly adjacent to a tooth extraction site, it was reported to produce osteonecrosis of the jaw. ${ }^{[56]}$

\section{Oral and periodontal effects of nicotine}

In some studies, it has been reported that nicotine impairs gingival blood flow ${ }^{[57]}$ and leads to local vasoconstrictive effects. ${ }^{[58]}$ It has been reported that chronic use of nicotine products could lead to dose-dependent suppression of gingival bleeding. ${ }^{[59]}$ However, smoking cessation improves gingival blood flow and gingival crevicular fluid (GCF) flow in humans. ${ }^{[60]}$ This impairment of normal blood and GCF flow poses potential issues in the modification of the desired response in periodontal healing and can affect the risk profiles for oral and dental pathology such as dental caries 
and Candidiasis. ${ }^{[43-45]}$ Furthermore, nicotine binds directly to the root surfaces and results in impaired gingival fibroblast attachment to those periodontally involved root surfaces. Katti et al. reported that nicotine levels can be significantly reduced by root planning in the course of periodontal debridement procedures, suggesting the importance of professional oral health maintenance in patients on nicotine products. ${ }^{[61]}$

Similarly, nicotine has been implicated as a standalone modifying factor in periodontal destruction by the way of inducing COX-2 expression in human gingival fibroblasts, ${ }^{[62]}$ inducing higher levels of interleukin-1 and interleukin-6 in gingival keratinocytes and fibroblasts, ${ }^{[63,64]}$ upregulating lipopolysaccharide-mediated human monocyte secretion of prostaglandin-E2, ${ }^{[65]}$ and matrix-metalloproteinases ${ }^{[66]}$ which degrade connective tissue, as well as having a stimulatory effect on polymorphonuclear cell apoptosis. ${ }^{[50]}$ These processes lead to an upregulation of the inflammatory response and promote the destruction of the tissue.

The negative effects on the immune response, blood flow, and salivary status have the capacity to modify periodontal disease, periodontal treatment outcomes, postsurgical healing and implant placement, and maintenance outcomes. The compromised healing response in both hard and soft oral tissues, as identified above leads to the progression of periodontal disease and impairs surgical healing of extraction sites and other regenerative, mucogingival, and implant surgical procedures. ${ }^{[51]}$

\section{Adverse Effects of Nicotine Replacement Therapy on Oral Health}

The smoking status of the patient is always considered in dental management; however, the effect of NRT usage and its implications are not routinely considered in the oral and dental management of patients.

One of the most commonly reported side effects of nicotine and NRT use is dry mouth, resulting in an impairment of the buffering capacity of the saliva. ${ }^{[16]}$ Modification of the quality and quantity of saliva by NRT may result in an increase in the patient's caries-risk profile and increased the risk of such conditions as candidiasis, oral mucositis, mouth soreness, taste impairment, dryness, and cracking of the vestibular tissue, and multiple issues for denture wearers as a result of a dry oral cavity including difficulty in speech. ${ }^{[2-45]}$ Nicotine delivered orally may also produce other forms of oral changes leading to discomfort, including numbness and tingling, hyperkeratosis, oral lichenoid reactions, burning mouth syndrome, and localized mucosal irritation. ${ }^{[17,67,68]}$ Nicotine is a carcinogen and has been shown to modify the progression of oral cancer. Its consumption through an NRT product orally may place a patient at risk of oral neoplastic changes. ${ }^{[69-73]}$ There is limited research of NRT links to oral malignancy and impacts in conjunction with head-and-neck radiotherapy.

\section{Adverse Impact of Nicotine or Nicotine Replacement Therapy in Periodontal and Oral Surgical Management}

Smoking cessation in the management of periodontal conditions is well established, due to its major impact factor in the posttreatment and modifying factor in the progression of periodontitis. ${ }^{[74-77]}$ Similar complications in postsurgical outcomes following dental implant placement, hard- and soft-tissue grafting procedures, surgical exposure for orthodontics, and excisional procedures are reported.

The above issues are due to nicotine's effects on the immune system and complications of the normal postsurgical healing response in the oral cavity, with delayed healing. An extraction site with impaired blood flow will take longer to heal, and therefore produce an increased risk of secondary infection, impaired soft tissue and bone healing, as well as an extended period of the patient discomfort with a poorly healing socket. This is particularly relevant when the oral NRT product is applied directly adjacent to the healing site (s) and periodontally treated, operative sites after a crown lengthening or mucogingival procedures.

Incidences of postoperative discomfort and superinfection, resulting in opportunistic infections such as candidiasis in the oral environment have been reported ${ }^{[43,44]}$ For patients on bisphosphonate medications, NRT may produce an increased risk of medication-related osteonecrosis of the jaws in the absence of other risk factors or other medical complications such as poorly controlled diabetes. ${ }^{[56]}$

\section{Smoking Cessation and the Dental Professional}

The practitioner, on considering future treatment directions and clinical management of a periodontal patient may encounter differences in healing and treatment outcomes as a result of the direct/indirect impacts of NRT in the absence of any significant medical implications in a susceptible individual. The clinician should have knowledge of NRT's oral and dental effects on the patient, for accurate diagnosis, appropriate management and minimization, or elimination of risk factors. Dolan et al. found that $65 \%$ of dentists advise smoking cessation, few provided specific counseling on cessation methods, strategies, or routine prescription of products, as this is not a part of the general dental practice. ${ }^{[78]}$ At present, there are no guidelines readily available for counseling the patient in the use of NRT and smoking cessation advice, support/counseling as a routine part of the general dental practice. ${ }^{[78]}$

The primary message that the health professionals' recommends in relation to these products is obtained from the manufacturers' advice notes on the effectiveness of such products in smoking cessation. Although various research has highlighted the efficacy of NRT contribution in smoking cessation, ${ }^{[7,8,79]}$ the adverse effects of NRT is usually left to the patient themselves. 
A deeper understanding of the impact that NRT products have on the oral cavity and the role they play in dental management will have far-reaching positive outcomes for patients, as well as instilling confidence in clinician's advice on smoking cessation. ${ }^{[80]}$ There is no formal training provided in the Australian dental school curriculum, regarding the provision of smoking cessation services in a dental setting for oral health professionals. Most patients are simply told that they "must quit smoking, ${ }^{[78]}$ sometimes followed by a recommendation for NRT in general, rather than advice on specific products or their use. Follow-up usually centers on patients' success with cessation rather than considering adverse events that may be associated with NRT.

Of interest to dentists are the questions raised regarding oral and dental pathology risks, as well as postsurgical, periodontal, and implant outcomes for patients utilizing NRT and how to proceed. This is due to increased caries risk, xerostomia, oral mucosal changes, oral cancer, and development of the oral lesions. Currently, there is inadequate knowledge with regard to how NRT may modify treatment outcomes, risk profiles, or the modification of the natural history of particular diseases or conditions.

Research has highlighted patients' safety concerns and fears with respect to NRT products, so the provision of accurate safety information will ensure the highest levels of compliance with therapy and successful smoking cessation. ${ }^{[80-82]}$ These studies present a strong case for furthering the available knowledge regarding the specific potential adverse effects of NRPs for health professionals prescribing the use of NRT and managing patients using NRT.

Given the imperative need for evidence-based practice in all health-care settings, ${ }^{[83]}$ it is desirable that further information can be obtained regarding specific effects of NRT, to aid diagnosis and prevention of adverse effects on the oral and dental tissues for all health professionals, as well as to ensure appropriate recommendations are made regarding the use of particular products and to ensure the best chances of cessation for patients. ${ }^{[80-82]}$ Pharmaceutical companies and manufacturers of NRT products might also benefit from this knowledge in furthering the development of NRT products or the provision of information regarding their appropriate usage.

\section{Conclusions}

While the clinical implications of patients' smoking status are well known in the management and treatment of the dental patient, the effects of NRT usage are not routinely considered in general patient management. The current body of evidence indicates a lack of knowledge of the effects on the oral cavity of the use of NRT. Further investigation and subsequent promotion of the information to oral health professionals will ensure better dental and oral health outcomes.

\section{Financial support and sponsorship}

Nil.

\section{Conflicts of interest}

There are no conflicts of interest.

\section{References}

1. Collins D, Lapsley H. The social costs of smoking in Australia. N S W Public Health Bull 2004;15:92-4.

2. Moore D, Aveyard P, Connock M, Wang D, Fry-Smith A, Barton P. Effectiveness and safety of nicotine replacement therapy assisted reduction to stop smoking: Systematic review and meta-analysis. BMJ 2009;338:b1024.

3. GBD 2015 Tobacco Collaborators. Smoking prevalence and attributable disease burden in 195 countries and territories, 1990-2015: A systematic analysis from the Global Burden of Disease Study 2015. Lancet 2017;389:1885-906

4. Scollo MM, Winstanley MH. Tobacco in Australia: Facts and Issues. Melbourne: Cancer Council Victoria; 2015. Available from: http:// www.tobaccoinaustralia.org.au/chapter-3-health-effects/3-3-smokingand-cancer. [Last accessed on 2019 Dec 03].

5. Jamerson BD, Nides M, Jorenby DE, Donahue R, Garrett P, Johnston JA, et al. Late-term smoking cessation despite initial failure: An evaluation of bupropion sustained release, nicotine patch, combination therapy, and placebo. Clin Ther 2001;23:744-52.

6. Fernö O. Conversation with ove fernö. Addiction 1994;89:1215-26.

7. Stead LF, Perera R, Bullen C, Mant D, Hartmann-Boyce J, Cahill K, et al. Nicotine replacement therapy for smoking cessation. Cochrane Database Syst Rev 2012;11:CD000146.

8. Silagy C, Mant D, Fowler G, Lodge M. Meta-analysis on efficacy of nicotine replacement therapies in smoking cessation. Lancet 1994;343:139-42.

9. Hjalmarson AI. Effect of nicotine chewing gum in smoking cessation. A randomized, placebo-controlled, double-blind study. JAMA 1984;252:2835-8.

10. Liu Y, Liu BA. Enhanced proliferation, invasion, and epithelial-mesenchymal transition of nicotine-promoted gastric cancer by periostin. World J Gastroenterol 2011;17:2674-80.

11. Hjalmarson A, Nilsson F, Sjöström L, Wiklund O. The nicotine inhaler in smoking cessation. Arch Intern Med 1997;157:1721-8.

12. Shin VY, Cho CH. Nicotine and gastric cancer. Alcohol 2005;35:259-64.

13. Grana R, Benowitz N, Glantz SA. E-cigarettes: A scientific review. Circulation 2014;129:1972-86.

14. Shiffman S, Fant RV, Buchhalter AR, Gitchell JG, Henningfield JE. Nicotine delivery systems. Expert Opin Drug Deliv 2005;2:563-77.

15. Bohadana A, Nilsson F, Rasmussen T, Martinet Y. Nicotine inhaler and nicotine patch as a combination therapy for smoking cessation: A randomized, double-blind, placebo-controlled trial. Arch Intern Med 2000;160:3128-34.

16. Haustein KO, Krause J, Haustein H, Rasmussen T, Cort N. Comparison of the effects of combined nicotine replacement therapy vs. Cigarette smoking in males. Nicotine Tob Res 2003;5:195-203.

17. Mills EJ, Wu P, Lockhart I, Wilson K, Ebbert JO. Adverse events associated with nicotine replacement therapy (NRT) for smoking cessation. A systematic review and meta-analysis of one hundred and twenty studies involving 177,390 individuals. Tob Induc Dis 2010;8:8.

18. Blondal T, Gudmundsson LJ, Olafsdottir I, Gustavsson G, Westin A. Nicotine nasal spray with nicotine patch for smoking cessation: randomised trial with six year follow up. BMJ 1999;318:285-8.

19. Karaconji IB. Facts about nicotine toxicity. Arh Hig Rada Toksikol 2005;56:363-71.

20. Rassool GH. Ch. 9. Nicotine. Addiction for Nurses. Oxford, UK: WileyBlackwell Publishing; 2010. p. 90-9. Available from: http://www.wiley. com/wiley-blackwell. [Last accessed on 2019 Dec 02].

21. Roe FJ. Effects of nicotine on biological-systems - Hamburg, frg 28-30 June 1990. Trends Pharmacol Sci 1990;11:346-7.

22. Yildiz D. Nicotine, its metabolism and an overview of its biological effects. Toxicon 2004;43:619-32.

23. Benowitz NL. Pharmacology of nicotine: Addiction and therapeutics. Annu Rev Pharmacol Toxicol 1996;36:597-613.

24. Riebel GD, Boden SD, Whitesides TE, Hutton WC. The effect of 
nicotine on incorporation of cancellous bone graft in an animal model. Spine (Phila Pa 1976) 1995;20:2198-202.

25. Geng Y, Savage SM, Johnson LJ, Seagrave J, Sopori ML. Effects of nicotine on the immune response. I. Chronic exposure to nicotine impairs antigen receptor-mediated signal transduction in lymphocytes. Toxicol Appl Pharmacol 1995;135:268-78.

26. Geng Y, Savage SM, Razani-Boroujerdi S, Sopori ML. Effects of nicotine on the immune response. II. Chronic nicotine treatment induces T cell anergy. J Immunol 1996;156:2384-90.

27. Kalra R, Singh SP, Pena-Philippides JC, Langley RJ, Razani-Boroujerdi S, Sopori ML. Immunosuppressive and anti-inflammatory effects of nicotine administered by patch in an animal model. Clin Diagn Lab Immunol 2004;11:563-8.

28. Singh SP, Kalra R, Puttfarcken P, Kozak A, Tesfaigzi J, Sopori ML. Acute and chronic nicotine exposures modulate the immune system through different pathways. Toxicol Appl Pharmacol 2000;164:65-72.

29. McAllister-Sistilli CG, Caggiula AR, Knopf S, Rose CA, Miller AL, Donny EC. The effects of nicotine on the immune system. Psychoneuroendocrinology 1998;23:175-87.

30. de Almeida TF, Romana-Souza B, Machado S, Abreu-Villaça Y, Monte-Alto-Costa A. Nicotine affects cutaneous wound healing in stressed mice. Exp Dermatol 2013;22:524-9.

31. Mosely LH, Finseth F, Goody M. Nicotine and its effect on wound healing. Plast Reconstr Surg 1978;61:570-5.

32. Hollinger JO, Schmitt JM, Hwang K, Soleymani P, Buck D. Impact of nicotine on bone healing. J Biomed Mater Res 1999;45:294-301.

33. Nakayama Y, Mezawa M, Araki S, Sasaki Y, Wang S, Han J, et al. Nicotine suppresses bone sialoprotein gene expression. J Periodontal Res 2009;44:657-63.

34. Saito Y, Sato S, Oginuma T, Saito Y, Arai Y, Ito K. Effects of nicotine on guided bone augmentation in rat calvarium. Clin Oral Implants Res 2013;24:531-5.

35. Raulin LA, McPherson JC $3^{\text {rd }}$, McQuade MJ, Hanson BS. The effect of nicotine on the attachment of human fibroblasts to glass and human root surfaces in vitro. J Periodontol 1988;59:318-25.

36. Tanur E, McQuade MJ, McPherson JC, Al-Hashimi IH, Rivera-Hidalgo F. Effects of nicotine on the strength of attachment of gingival fibroblasts to glass and non-diseased human root surfaces. J Periodontol 2000;71:717-22.

37. Tipton DA, Dabbous MK. Effects of nicotine on proliferation and extracellular matrix production of human gingival fibroblasts in vitro. J Periodontol 1995;66:1056-64.

38. Benowitz NL, Gourlay SG. Cardiovascular toxicity of nicotine: Implications for nicotine replacement therapy. J Am Coll Cardiol 1997;29:1422-31.

39. Piao WH, Campagnolo D, Dayao C, Lukas RJ, Wu J, Shi FD. Nicotine and inflammatory neurological disorders. Acta Pharmacol Sin 2009;30:715-22

40. Cardinale A, Nastrucci C, Cesario A, Russo P. Nicotine: Specific role in angiogenesis, proliferation and apoptosis. Crit Rev Toxicol 2012;42:68-89.

41. Konishi $\mathrm{H}, \mathrm{Wu}$ J, Cooke JP. Chronic exposure to nicotine impairs cholinergic angiogenesis. Vasc Med 2010;15:47-54.

42. Altarawneh S, Bencharit S, Mendoza L, Curran A, Barrow D, Barros S, et al. Clinical and histological findings of denture stomatitis as related to intraoral colonization patterns of Candida albicans, salivary flow, and dry mouth. J Prosthodont 2013;22:13-22.

43. Sapp JP, Eversole LR, Wysocki GP. Epithelial disorders. Contemporary Oral and Maxillofacial Pathology. $2^{\text {nd }}$ ed., Ch. 6. St Louis, Mo: Mosby; 2004. p. 190-1.

44. Scully C, Ebrary I. Oral and Maxillofacial Medicine: The Basis of Diagnosis and Treatment. New York, Edinburgh: Churchill Livingstone; 2008.

45. Sreebny LM, Vissink A, ebrary I. Dry Mouth: The Malevolent Symptom: A Clinical Guide. Ames, Iowa: Wiley-Blackwell; 2010. p. 245.

46. Nouri-Shirazi M, Guinet E. Evidence for the immunosuppressive role of nicotine on human dendritic cell functions. Immunology 2003;109:365-73

47. Saeed R, Varma S, Peng T, Tracey KJ, Metz CN. The immunosuppressive effects of nicotine on endothelial cell activation and leukocyte trafficking in vivo. J Leukoc Biol 2004; p.37-8.

48. Takahashi HK, Iwagaki H, Hamano R, Kanke T, Liu K, Sadamori H, et al. The immunosuppressive effects of nicotine during human mixed lymphocyte reaction. Eur J Pharmacol 2007;559:69-74.

49. Pabst MJ, Pabst KM, Collier JA, Coleman TC, Lemons-Prince ML, Godat MS, et al. Inhibition of neutrophil and monocyte defensive functions by nicotine. J Periodontol 1995;66:1047-55.

50. Mariggiò MA, Guida L, Laforgia A, Santacroce R, Curci E, Montemurro $\mathrm{P}$, et al. Nicotine effects on polymorphonuclear cell apoptosis and lipopolysaccharide-induced monocyte functions. A possible role in periodontal disease? J Periodontal Res 2001;36:32-9.

51. Malhotra R, Kapoor A, Grover V, Kaushal S. Nicotine and periodontal tissues. J Indian Soc Periodontol 2010;14:72-9.

52. Thomé GR, Oliveira LS, Schetinger MR, Morsch VM, Spanevello RM, Fiorenza AM, et al. Nicotine alters the ectonucleotidases activities in lymphocytes: In vitro and in vivo studies. Biomed Pharmacother 2012;66:206-12.

53. Theiss SM, Boden SD, Hair G, Titus L, Morone MA, Ugbo J. The effect of nicotine on gene expression during spine fusion. Spine (Phila $\mathrm{Pa}$ 1976) 2000;25:2588-94.

54. Austin GW, Cuenin MF, Hokett SD, Peacock ME, Sutherland DE, Erbland JF, et al. Effect of nicotine on fibroblast beta 1 integrin expression and distribution in vitro. J Periodontol 2001;72:438-44.

55. Zhou J, Olson BL, Windsor LJ. Nicotine increases the collagen-degrading ability of human gingival fibroblasts. J Periodontal Res 2007;42:228-35.

56. Loo YK. Nicotine-induced osteonecrosis. A case report. Dent Update 2009;36:289-91

57. Bergström J. Smoking may impede gingival bleeding. J Evid Based Dent Pract 2005;5:29-30.

58. Mavropoulos A, Aars H, Brodin P. Hyperaemic response to cigarette smoking in healthy gingiva. J Clin Periodontol 2003;30:214-21.

59. Dietrich T, Bernimoulin JP, Glynn RJ. The effect of cigarette smoking on gingival bleeding. J Periodontol 2004;75:16-22.

60. Morozumi T, Kubota T, Sato T, Okuda K, Yoshie H. Smoking cessation increases gingival blood flow and gingival crevicular fluid. J Clin Periodontol 2004;31:267-72.

61. Katti N, Mohanty D, Asif K, Shatapathy N. Determination of efficacy of root planing in removal of nicotine from periodontally involved teeth of smokers. Chron Young Sci 2012;3:160.

62. Chang YC, Tsai CH, Yang SH, Liu CM, Chou MY. Induction of cyclooxygenase-2 mRNA and protein expression in human gingival fibroblasts stimulated with nicotine. J Periodontal Res 2003;38:496-501.

63. Johnson GK, Organ CC. Prostaglandin E2 and interleukin-1 concentrations in nicotine-exposed oral keratinocyte cultures. J Periodontal Res 1997;32:447-54.

64. Wendell KJ, Stein SH. Regulation of cytokine production in human gingival fibroblasts following treatment with nicotine and lipopolysaccharide. J Periodontol 2001;72:1038-44.

65. Payne JB, Johnson GK, Reinhardt RA, Dyer JK, Maze CA, Dunning DG. Nicotine effects on PGE2 and IL-1 beta release by LPS-treated human monocytes. J Periodontal Res 1996;31:99-104.

66. Kim YS, Shin SI, Kang KL, Chung JH, Herr Y, Bae WJ, et al. Nicotine and lipopolysaccharide stimulate the production of MMPs and prostaglandin E2 by hypoxia-inducible factor-1 $\alpha$ up-regulation in human periodontal ligament cells. J Periodontal Res 2012;47:719-28.

67. Mortazavi H, Safi Y, Baharvand M, Jafari S, Anbari F, Rahmani S. Oral White Lesions: An Updated Clinical Diagnostic Decision Tree. Dent J (Basel) 2019,7:15. Doi: 10.3390/dj7010015.

68. Naudi KB, Felix DH. Nicotine replacement lozenges: Abuse-related hyperkeratosis of the lateral border of the tongue. A case report. Br Dent J 2007;203:305-6.

69. Chiang $\mathrm{CH}$. Nicotine contributes to oral cancer by promotion of cell invasion through ASAP1 signaling pathway. Cancer Res 2013;73:6-10.

70. Gemenetzidis E, Bose A, Riaz AM, Chaplin T, Young BD, Ali M, et al. FOXM1 upregulation is an early event in human squamous cell carcinoma and it is enhanced by nicotine during malignant transformation. PLoS One 2009;4:e48-9.

71. Hamraz M, Salimi M, Esfahani M, Sedaghati B, Aslani HR, Bazarchi A. Nicotine effect on P-ERK, COX-2, PGE2 and VEGF expression in oral 
squamous cancer. J Biotechnol 2010;150:442-2.

72. Viswanath K, Herbst RS, Land SR, Leischow SJ, Shields PG. And Writing Committee for the AACR Task Force on Tobacco and Cancer, Cancer Res 2010;70:3419-30. DOI: 10.1158/0008-5472.CAN-10-1087.

73. Xu J, Huang H, Pan C, Zhang B, Liu X, Zhang L. Nicotine inhibits apoptosis induced by cisplatin in human oral cancer cells. Int J Oral Maxillofac Surg 2007;36:739-44.

74. Bergström J. Cigarette smoking as risk factor in chronic periodontal disease. Community Dent Oral Epidemiol 1989;17:245-7.

75. Bergström J, Eliasson S, Dock J. Exposure to tobacco smoking and periodontal health. J Clin Periodontol 2000;27:61-8.

76. Preber H, Bergström J. The effect of non-surgical treatment on periodontal pockets in smokers and non-smokers. J Clin Periodontol 1986;13:319-23.

77. Preber H, Bergström J. Effect of cigarette smoking on periodontal healing following surgical therapy. J Clin Periodontol 1990;17:324-8.

78. Dolan TA, McGorray SP, Grinstead-Skigen CL, Mecklenburg R. Tobacco control activities in U.S. dental practices. J Am Dent Assoc
1997;128:1669-79.

79. Henningfield JE. Nicotine medications for smoking cessation. N Engl J Med 1995;333:1196-203.

80. Ferguson SG, Gitchell JG, Shiffman S, Sembower MA, Rohay JM, Allen J. Providing accurate safety information may increase a smoker's willingness to use nicotine replacement therapy as part of a quit attempt. Addict Behav 2011;36:713-6.

81. Shiffman S, Ferguson SG, Rohay J, Gitchell JG. Perceived safety and efficacy of nicotine replacement therapies among US smokers and ex-smokers: Relationship with use and compliance. Addiction 2008;103:1371-8.

82. Vogt F, Hall S, Marteau TM. Understanding why smokers do not want to use nicotine dependence medications to stop smoking: Qualitative and quantitative studies. Nicotine Tob Res 2008;10:1405-13.

83. Ismail AI, Bader JD, ADA Council on Scientific Affairs and Division of Science, Journal of the American Dental Association. Evidence-based dentistry in clinical practice. J Am Dent Assoc 2004; $135: 78-83$.

\section{"Quick Response Code" link for full text articles}

The journal issue has a unique new feature for reaching to the journal's website without typing a single letter. Each article on its first page has a "Quick Response Code". Using any mobile or other hand-held device with camera and GPRS/other internet source, one can reach to the full text of that particular article on the journal's website. Start a QR-code reading software (see list of free applications from http://tinyurl.com/ yzlh2tc) and point the camera to the QR-code printed in the journal. It will automatically take you to the HTML full text of that article. One can also use a desktop or laptop with web camera for similar functionality. See http://tinyurl.com/2bw7fn3 or http://tinyurl.com/3ysr3me for the free applications. 